Article

\title{
Preparation of Vanadium Nitride Using a Thermally Processed Precursor with Coating Structure
}

\author{
Jingli Han 1,2,3, Yimin Zhang 1,2,3,4,*, Tao Liu 1,2,3, Jing Huang 1,2,3, Nannan Xue 1,3 and \\ Pengcheng $\mathrm{Hu}^{1,2,3}$ \\ 1 College of Resource and Environment Engineering, Wuhan University of Science and Technology, \\ Wuhan 430081, China; hanjingli93@126.com (J.H.); liutao@wust.edu.cn (T.L.); huangjing@wust.edu.cn (J.H.); \\ cbdis@aliyun.com (N.X.); hpcmy126@126.com (P.H.) \\ 2 Hubei Collaborative Innovation Center of High Efficient Utilization for Vanadium Resources, \\ Wuhan 430081, China \\ 3 Hubei Provincial Engineering Technology Research Center of High Efficient Cleaning Utilization for Shale \\ Vanadium Resource, Wuhan 430081, China \\ 4 College of Resource and Environment Engineering, Wuhan University of Technology, Wuhan 430070, China \\ * Correspondence: zhangyimin@wust.edu.cn; Tel.: +86-027-6886-2057
}

Received: 30 July 2017; Accepted: 5 September 2017; Published: 11 September 2017

\begin{abstract}
A new effective method is proposed to prepare vanadium nitride (VN) via carbothermal reduction-nitridation (CRN) of the precursor, obtained by adding carbon black (C) to the stripping solution during the vanadium recovery from black shale. VN was successfully prepared at a low temperature of $1150{ }^{\circ} \mathrm{C}$ for only $1 \mathrm{~h}$ with a $\mathrm{C} / \mathrm{V}_{2} \mathrm{O}_{5}$ mass ratio of 0.30 in $\mathrm{N}_{2}$ atmosphere, but a temperature of $1300-1500{ }^{\circ} \mathrm{C}$ is required for several hours in the traditional CRN method. The low synthesis temperature and short period for the preparation of $\mathrm{VN}$ was due to the vanadium-coated carbon structure of the precursor, which enlarged the contact area between reactants significantly and provided more homogeneous chemical composition. In addition, the simultaneous direct reduction and indirect reduction of the interphase caused by the coating structure obviously accelerated the reaction. The phase evolution of the precursor was as follows: $\left(\mathrm{NH}_{4}\right)_{2} \mathrm{~V}_{6} \mathrm{O}_{16} \cdot 1.5 \mathrm{H}_{2} \mathrm{O} \rightarrow \mathrm{V}_{2} \mathrm{O}_{5} \rightarrow$ $\mathrm{V}_{6} \mathrm{O}_{13} \rightarrow \mathrm{VO}_{2} \rightarrow \mathrm{V}_{4} \mathrm{O}_{7} \rightarrow \mathrm{V}_{2} \mathrm{O}_{3} \rightarrow \mathrm{VC} \rightarrow \mathrm{VN}$. The precursor converted to $\mathrm{V}_{6} \mathrm{O}_{13}$ and $\mathrm{VO}_{2}$ completely after being calcined at $550{ }^{\circ} \mathrm{C}$, indicating that the pre-reduction of $\mathrm{V}_{2} \mathrm{O}_{5}$ in the traditional CRN method can be omitted. This method combined the synthesis of $\mathrm{VN}$ with the vanadium extraction creatively, having the advantages of simple reaction conditions, low cost and short processing time.
\end{abstract}

Keywords: vanadium nitride; precursor; phase evolution; nitrogen content; black shale

\section{Introduction}

Vanadium nitride $(\mathrm{VN})$ has received increasing attention in recent years due to its typical properties including extreme hardness, high melting point, wear and corrosion resistance, good electric and thermal conductivity, high-temperature stability, as well as good catalytic activity. It can be widely used as iron and steel additive [1,2], electrode [3,4], catalyst [5,6], superconductor [7], and coating [8,9]. The frequent application of $\mathrm{VN}$, as an important steel additive, can be ascribed to its beneficial effect on fine grain and precipitation strengthening, which can improve the comprehensive performance of steel and reduce the cost of the smelting process by using nitrogen to reduce the vanadium content of steel [10].

The traditional procedure for the synthesis of $\mathrm{VN}$ is the process of carbothermal reduction- nitridation $(\mathrm{CRN})$ of $\mathrm{V}_{2} \mathrm{O}_{5}$ in $\mathrm{N}_{2}$ at a high temperature of $1500{ }^{\circ} \mathrm{C}$ for $3 \mathrm{~h}$ with a $\mathrm{N}_{2}$ flow rate of $13.3 \times 10^{-6} \mathrm{~m}^{3} \cdot \mathrm{s}^{-1}$ [11], and at $1400{ }^{\circ} \mathrm{C}$ with a $\mathrm{N}_{2}$ flow rate of $50 \mathrm{~L} \cdot \mathrm{h}^{-1}$, using a microwave method [12]. The low melting point $\left(670{ }^{\circ} \mathrm{C}\right)$ and the high saturation vapor pressure of $\mathrm{V}_{2} \mathrm{O}_{5}$ will result in a volatile loss of $\mathrm{V}_{2} \mathrm{O}_{5}$ near its 
melting point. Hence, the pre-reduction during transformation from $\mathrm{V}_{2} \mathrm{O}_{5}$ to a high melting point and low-valent vanadium oxides below the melting point of $\mathrm{V}_{2} \mathrm{O}_{5}$ is necessary [13], resulting inevitably in a long reaction period. However, using the low-valent vanadium oxides will increase the production cost due to the higher price compared to $\mathrm{V}_{2} \mathrm{O}_{5}$. In addition to the traditional CRN method, $\mathrm{VN}$ was prepared by thermal liquid-solid reaction [14]: Ammonolysis of precursor compounds of metal [7], self-propagating high-temperature synthesis [15], sol-gel method [16], chemical vapor deposition [17], mechanical alloying [18] and other methods [19,20]. However, most methods are plagued by the presence of air-sensitive or toxic reagents, expensive equipment and raw materials, elevated temperatures and long reaction time, which limit its large-scale production and application. Therefore, there is a need for a simple synthesis route of $\mathrm{VN}$. Thermal processing precursor, as a novel method to prepare metal nitrides, has gradually become a research hotspot. Zhao et al. [21] synthesized VN nanopowders by thermal nitridation of the precursor obtained by physically drying an aqueous solution of ammonium vanadate $\left(\mathrm{NH}_{4} \mathrm{VO}_{3}\right)$ and nanometer carbon black. $(\mathrm{Cr}, \mathrm{V})_{2}(\mathrm{C}, \mathrm{N})$ solid solution powders were synthesized by $\mathrm{CRN}$ of the precursor, prepared by heating admixtures of ammonium dichromate $\left(\left(\mathrm{NH}_{4}\right)_{2} \mathrm{Cr}_{2} \mathrm{O}_{7}\right), \mathrm{NH}_{4} \mathrm{VO}_{3}$, and carbon black in distilled water with continuous stirring [22]. These methods can reduce the synthesizing temperature greatly, but the production cost remained high due to the use of de-ionized water, $\mathrm{NH}_{4} \mathrm{VO}_{3}$ and nanometer carbon black, indicating the strong demand of a simple, low-cost and low-temperature approach to synthesize VN. Moreover, the formation process and microstructure of the precursor and its promoting effect on the preparation of metal nitrides were not discussed.

In China, most of the vanadium resources exist in the form of black shale, so the utilization and exploitation of black shale is an essential way to recover vanadium [23]. The vanadium recovery from black shale was investigated using a pyro-hydrometallurgical process specifically including roasting, acid leaching, purification, and chemical precipitation [24-26]. Solvent extraction was the most commonly adopted process to purify the acid leaching solution for better selectivity and economy $[27,28]$. After solvent extraction and stripping, vanadium can be precipitated from the stripping solution with acidic ammonium salt [29]. In view of the preparation method of precursor $[7,21,22]$ in the synthesis of $\mathrm{VN}$, and the application of the precipitation method [30] to synthesize $\mathrm{Pb}\left(\mathrm{Mg}_{1 / 3} \mathrm{Nb}_{2 / 3}\right) \mathrm{O}_{3}$ ceramic, it may be feasible to prepare the precursor during the vanadium precipitation from the stripping solution in the process of vanadium extraction from black shale, to synthesize VN. This method revealed the merits of a low reaction temperature, short period, and a widely available, cheap vanadium source, which make it more practical, economical and efficient in industrial applications.

In this study, we combined the synthesis of $\mathrm{VN}$ with vanadium extraction from black shale for the first time by adding carbon black (C) to the stripping solution. First, the precursor containing the vanadium source and reducing material formed gradually during the vanadium precipitation, then the precursor was reduced and nitrided in the $\mathrm{N}_{2}$ atmosphere to yield $\mathrm{VN}$. The effects of the main reaction conditions on the nitrogen content $(\mathrm{N}$ content) in $\mathrm{VN}$ product were investigated. In order to explain the lower temperature and shorter time for the preparation of $\mathrm{VN}$ in comparison with the conventional CRN method: The phase and microstructure of the precursor were analyzed. In addition, the mechanism of preparing $\mathrm{VN}$ from the precursor was discussed through phase analysis, thermodynamic calculation, and thermogravimetric (TG) experiment.

\section{Experimental Section}

\subsection{Materials}

The stripping solution was obtained by blank roasting, acid leaching, solvent extraction and stripping of black shale obtained from Tongshan, China. The main chemical composition of the stripping solution is given in Table 1 , the concentration of $\mathrm{V}$ in the stripping solution is $20.63 \mathrm{~g} \cdot \mathrm{L}^{-1}$, while the major impurity ion is $\mathrm{Al}$ with the content of $5.78 \mathrm{~g} \cdot \mathrm{L}^{-1}$. The $\mathrm{pH}$ of the stripping solution is 
0.03. Carbon black containing $94.80 \%$ of carbon with the particle size of less than $0.074 \mathrm{~mm}$ was used as the reducing agent.

Table 1. Main chemical composition of the stripping solution.

\begin{tabular}{ccccccc}
\hline Element & $\mathbf{V}$ & $\mathbf{A l}$ & $\mathbf{F e}$ & $\mathbf{K}$ & $\mathbf{N a}$ & $\mathbf{P}$ \\
\hline Concentration $\left(\mathrm{g} \cdot \mathrm{L}^{-1}\right)$ & 20.63 & 5.78 & 0.06 & 0.34 & 0.42 & 0.1 \\
\hline
\end{tabular}

\subsection{Typical Procedure for the Preparation of $V N$}

The process flow sheet to prepare VN is shown in Figure 1. Typically, sodium chlorate $\left(\mathrm{NaClO}_{3}\right.$, AR (analytical reagent), $2.95 \mathrm{~g}$ ) was added to the stripping solution $(200 \mathrm{~mL})$ to oxidize vanadium (IV) to vanadium (V) in a temperature-controlled magnetic stirrer (SZCL-2A, Wuhan Keer Instrument Co., Ltd., Wuhan, China) at room temperature. After complete oxidation, a certain amount of carbon black was added to the solution and dispersed by stirring. The $\mathrm{pH}$ of the solution was adjusted to 1.8 with ammonia (AR), and then the solution was stirred to precipitate ammonium polyvanadate (APV) at $90^{\circ} \mathrm{C}$ for $1 \mathrm{~h}$. After solid-liquid separation by vacuum filtration (model SHB-III, Wuhan Keer Instrument Co., Ltd., Wuhan, China), the precursor was washed by water, dried in an oven, and then compressed into cylindrical blocks of $30 \mathrm{~mm}$ diameter at a pressure of $14 \mathrm{MPa}$. The cylindrical block was placed into the tubular atmosphere furnace (SGL-1700, Shanghai Institute of Optics and Fine Mechanics, Shanghai, China) with a certain flow rate of nitrogen $(99.999 \%)$. The sample was calcined to deaminize at $550{ }^{\circ} \mathrm{C}$ for $20 \mathrm{~min}$ and pre-reduced at $650{ }^{\circ} \mathrm{C}$ for $2.5 \mathrm{~h}$, and then heated to the desired temperature for reduction and nitridation for a certain of time. Subsequently, the product was cooled to room temperature in nitrogen atmosphere.

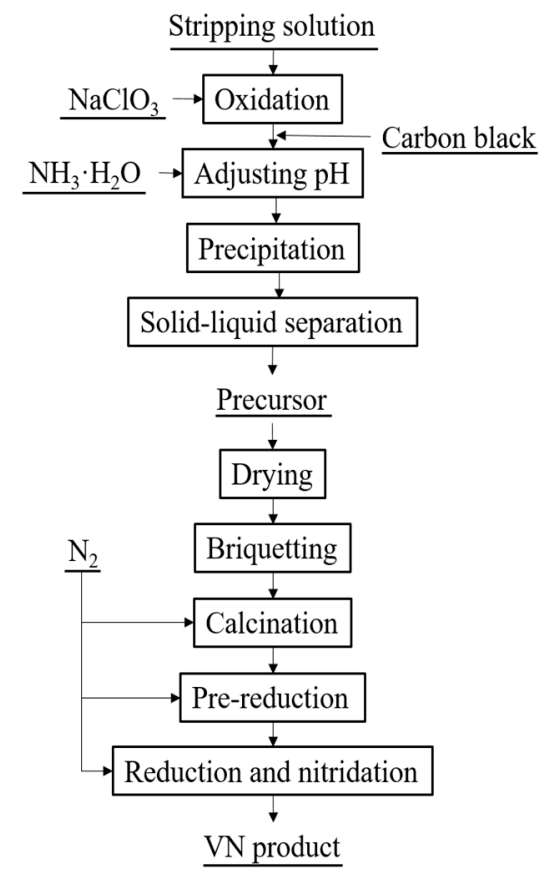

Figure 1. Process flow sheet for preparation of vanadium nitride (VN).

\subsection{Material Characterization}

The nitrogen content ( $\mathrm{N}$ content) was determined employing distillation-acid base titration analysis. The X-ray diffraction (XRD) patterns were obtained by using a Rigaku D/MAX-RB X-ray diffractometer (Rigaku, Akishima, Japan) with $\mathrm{Cu} K \alpha$ radiation to analyze the phase compositions in the products. Microscopic observation and elemental analysis (SEM-EDS; SEM: Scanning electron 
microscope; EDS: Energy-dispersive X-Ray spectroscope) was conducted using a JSM-IT300 scanning electron microscope (JEOL, Tokyo, Japan), equipped with an X-ACT energy dispersive spectrometer (Oxford Instruments, Oxford, UK). The thermogravimetric (TG) experiment was carried out by utilizing a STA449C analyzer (Netzsch, Selb, Germany) to change from room temperature to $1400{ }^{\circ} \mathrm{C}$ with a linear heating rate of $10{ }^{\circ} \mathrm{C} \cdot \mathrm{min}^{-1}$ under $\mathrm{N}_{2}$, and a gas flow rate of $50 \mathrm{~mL} \cdot \mathrm{min}^{-1}$.

\section{Results and Discussion}

\subsection{Effect of the Main Reaction Conditions on the N Content in VN Product}

\subsubsection{Effect of $\mathrm{C} / \mathrm{V}_{2} \mathrm{O}_{5}$ Mass Ratio}

The effect of $\mathrm{C} / \mathrm{V}_{2} \mathrm{O}_{5}$ mass ratio $\left(m\left(\mathrm{C}: \mathrm{V}_{2} \mathrm{O}_{5}\right)\right)$ on the $\mathrm{N}$ content in $\mathrm{VN}$ product is shown in Figure 2, obtained at a reaction temperature of $1250{ }^{\circ} \mathrm{C}$, a reaction time of $3 \mathrm{~h}$, and a $\mathrm{N}_{2}$ flow rate of $300 \mathrm{~mL} \cdot \mathrm{min}^{-1}$.
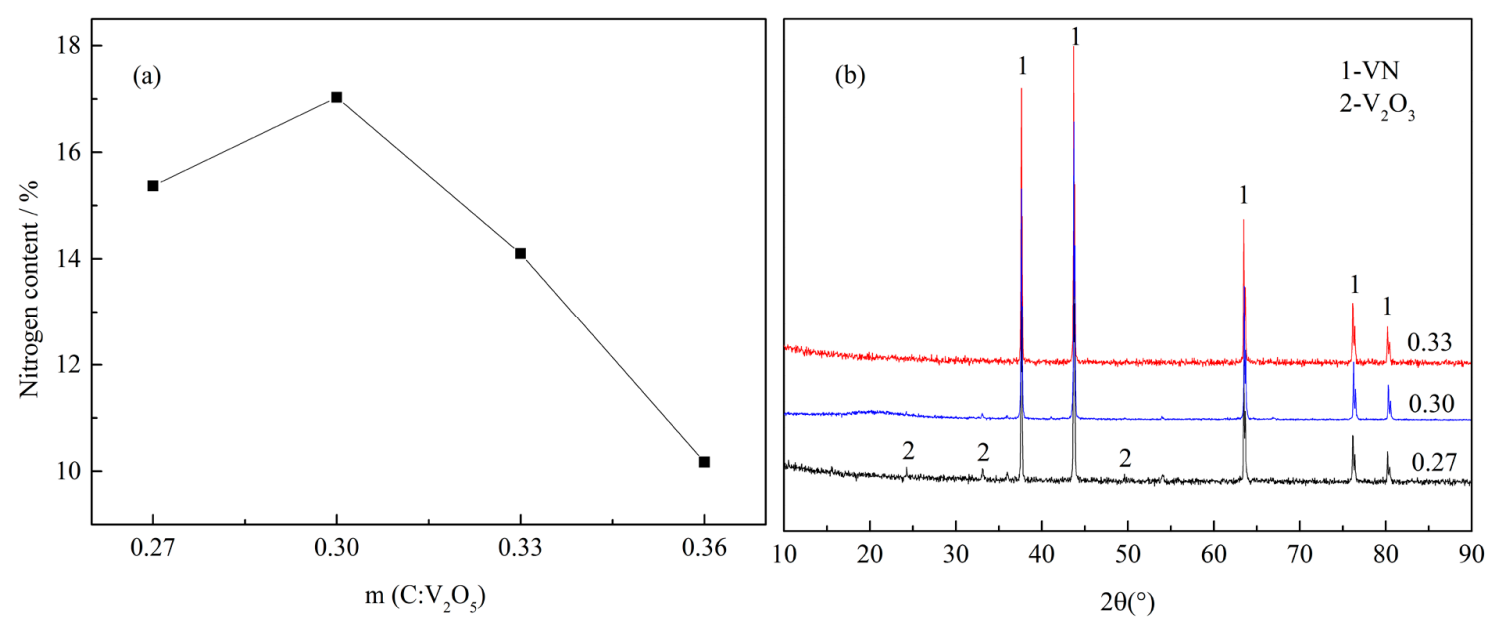

Figure 2. (a) Effect of $\mathrm{C} / \mathrm{V}_{2} \mathrm{O}_{5}$ mass ratio on the $\mathrm{N}$ content in $\mathrm{VN}$ product with a reaction temperature of $1250{ }^{\circ} \mathrm{C}$, reaction time of $3 \mathrm{~h}$ and $\mathrm{N}_{2}$ flow rate of $300 \mathrm{~mL} \cdot \mathrm{min}^{-1}$; (b) XRD (X-ray diffraction) patterns of the products obtained at different $\mathrm{C} / \mathrm{V}_{2} \mathrm{O}_{5}$ mass ratios with a reaction temperature of $1250{ }^{\circ} \mathrm{C}$, reaction time of $3 \mathrm{~h}$ and $\mathrm{N}_{2}$ flow rate of $300 \mathrm{~mL} \cdot \mathrm{min}^{-1}$.

As evident from Figure $2 \mathrm{a}$, the $m\left(\mathrm{C}: \mathrm{V}_{2} \mathrm{O}_{5}\right)$ has a pronounced effect on the $\mathrm{N}$ content in $\mathrm{VN}$, as the $\mathrm{N}$ content increased from $15.37 \%$ to $17.03 \%$ when $m\left(\mathrm{C}: \mathrm{V}_{2} \mathrm{O}_{5}\right)$ increased from 0.27 to 0.30 . Beyond 0.30 , the $\mathrm{N}$ content decreased from $17.03 \%$ to $10.17 \%$. The low $\mathrm{N}$ content was a possible result of the incomplete reduction, due to the shortage of carbon. This may be confirmed by the appearance of $\mathrm{V}_{2} \mathrm{O}_{3}$ (Figure $2 \mathrm{~b})$ at an $m\left(\mathrm{C}: \mathrm{V}_{2} \mathrm{O}_{5}\right)$ value of 0.27 . Conversely, when the $m\left(\mathrm{C}: \mathrm{V}_{2} \mathrm{O}_{5}\right)$ exceeded 0.30 , the excess carbon and the formation of vanadium carbonitride solid solution led to the decrease of the $\mathrm{N}$ content. However, there were no peaks that could be indexed to $\mathrm{C}$ or VC in Figure 2b, which was due to the amorphous state of carbon black and very similar diffraction patterns of $\mathrm{VC}$ and $\mathrm{VN}$ [31], respectively. Therefore, 0.30 was considered as the most suitable $\mathrm{C} / \mathrm{V}_{2} \mathrm{O}_{5}$ mass ratio for the reaction.

\subsubsection{Effect of Reaction Temperature}

To investigate the effect of the reaction temperature on the $\mathrm{N}$ content in $\mathrm{VN}$ product, several experiments were performed at a $\mathrm{C} / \mathrm{V}_{2} \mathrm{O}_{5}$ mass ratio of 0.30 , a reaction time of $3 \mathrm{~h}$ and a $\mathrm{N}_{2}$ flow rate of $300 \mathrm{~mL} \cdot \mathrm{min}^{-1}$. The experimental results are depicted in Figure 3. 

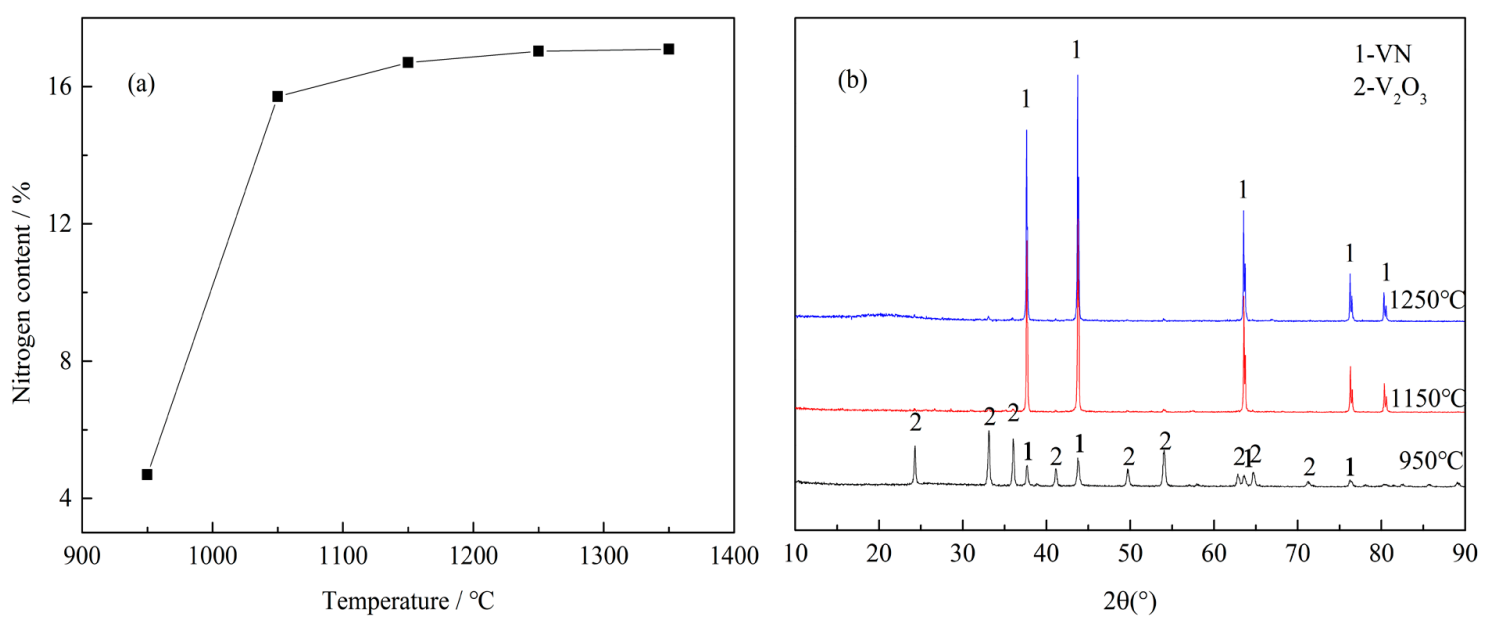

Figure 3. (a) Effect of reaction temperature on the $\mathrm{N}$ content in $\mathrm{VN}$ product with a $\mathrm{C} / \mathrm{V}_{2} \mathrm{O}_{5}$ mass ratio of 0.30 , reaction time of $3 \mathrm{~h}$ and $\mathrm{N}_{2}$ flow rate of $300 \mathrm{~mL} \cdot \mathrm{min}^{-1}$; (b) XRD patterns of the products obtained at different temperatures with a $\mathrm{C} / \mathrm{V}_{2} \mathrm{O}_{5}$ mass ratio of 0.30 , reaction time of $3 \mathrm{~h}$ and $\mathrm{N}_{2}$ flow rate of $300 \mathrm{~mL} \cdot \mathrm{min}^{-1}$

As shown in Figure 3a, the N content in VN product increased rapidly from $4.69 \%$ to $16.70 \%$ as the reaction temperature increased from $950{ }^{\circ} \mathrm{C}$ to $1150^{\circ} \mathrm{C}$; the $\mathrm{N}$ content then stayed at a constant level over the elevated reaction temperature. Figure $3 \mathrm{~b}$ exhibits XRD patterns of the products obtained at different temperatures. At $950{ }^{\circ} \mathrm{C}$, the peaks were identified as $\mathrm{V}_{2} \mathrm{O}_{3}$ and $\mathrm{VN}$, indicating that the reduction and nitridation of the precursor were not complete at a temperature as low as $950{ }^{\circ} \mathrm{C}$. The XRD patterns were identical and all diffraction peaks corresponded to $\mathrm{VN}$ at $1150^{\circ} \mathrm{C}$ and $1250{ }^{\circ} \mathrm{C}$, revealing that the precursor was reduced and nitrided almost completely. Hence, a reaction temperature of $1150{ }^{\circ} \mathrm{C}$ was chosen as the optimal condition in this experiment.

\subsubsection{Effect of Reaction Time}

The effect of reaction time on the $\mathrm{N}$ content in $\mathrm{VN}$ product was investigated under the conditions of a C/ $\mathrm{V}_{2} \mathrm{O}_{5}$ mass ratio of 0.30 , a reaction temperature of $1150{ }^{\circ} \mathrm{C}$ and a $\mathrm{N}_{2}$ flow rate of $300 \mathrm{~mL} \cdot \mathrm{min}^{-1}$. The results are shown in Figure 4.

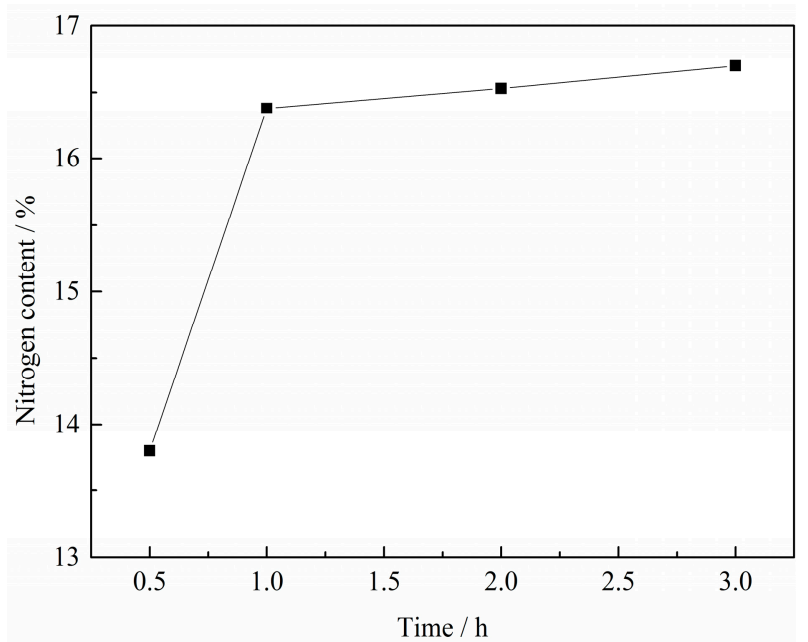

Figure 4. Effect of reaction time on the $\mathrm{N}$ content in $\mathrm{VN}$ product with a $\mathrm{C} / \mathrm{V}_{2} \mathrm{O}_{5}$ mass ratio of 0.30 , reaction temperature of $1150{ }^{\circ} \mathrm{C}$ and $\mathrm{N}_{2}$ flow rate of $300 \mathrm{~mL} \cdot \mathrm{min}^{-1}$. 
It can be observed that the $\mathrm{N}$ content in $\mathrm{VN}$ product increased strongly from $13.80 \%$ to $16.38 \%$ as the reaction time increased from $0.5 \mathrm{~h}$ to $1 \mathrm{~h}$ and then remained almost constant beyond $1 \mathrm{~h}$, which indicated that the reduction and nitridation of the precursor was almost complete at $1 \mathrm{~h}$. Thus, the optimum reaction time was determined to be $1 \mathrm{~h}$.

\subsubsection{Effect of $\mathrm{N}_{2}$ Flow Rate}

The effect of $\mathrm{N}_{2}$ flow rate on the $\mathrm{N}$ content in $\mathrm{VN}$ product was investigated under the conditions of a C/ $\mathrm{V}_{2} \mathrm{O}_{5}$ mass ratio of 0.30 , a reaction temperature of $1150{ }^{\circ} \mathrm{C}$ and a reaction time of $1 \mathrm{~h}$. The results are shown in Figure 5.

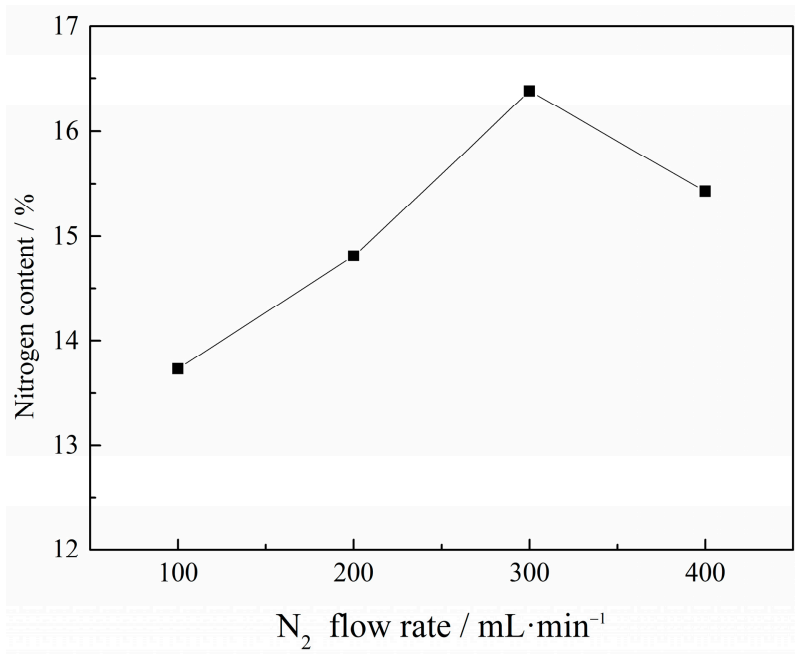

Figure 5. Effect of $\mathrm{N}_{2}$ flow rate on the $\mathrm{N}$ content in $\mathrm{VN}$ product with a $\mathrm{C} / \mathrm{V}_{2} \mathrm{O}_{5}$ mass ratio of 0.30 , reaction temperature of $1150{ }^{\circ} \mathrm{C}$ and reaction time of $1 \mathrm{~h}$.

Figure 5 indicates that the $\mathrm{N}_{2}$ flow rate substantially influenced the $\mathrm{N}$ content in VN product. The $\mathrm{N}$ content first rose from $13.73 \%$ to $16.38 \%$ and then decreased to $15.43 \%$ with an increasing $\mathrm{N}_{2}$ flow rate. There was an optimum $\mathrm{N}_{2}$ flow rate of $300 \mathrm{~mL} \cdot \mathrm{min}^{-1}$, at which a maximum $\mathrm{N}$ content was achieved. The flowing nitrogen can increase $\mathrm{N}_{2}$ partial pressure and decrease the $\mathrm{CO}$ partial pressure, which might accelerate the reduction and nitridation reactions. However, the rapid flowing nitrogen could not be sufficiently heated, and the contact time with vanadium oxides was too short to react adequately, resulting in decreased $\mathrm{N}$ content as the flow rate increased further. Therefore, $300 \mathrm{~mL} \cdot \mathrm{min}^{-1}$ was the optimal $\mathrm{N}_{2}$ flow rate.

\subsection{Phase and Microstructure Analyses of the Precursor}

Although an appropriate flow rate of nitrogen can promote the synthesis of $\mathrm{VN}$, high reaction temperature and long reaction time were still required in the synthesis of $\mathrm{VN}$ with the flow of nitrogen in the tubular furnace $[11,12]$. Compared with a temperature of $1300-1500{ }^{\circ} \mathrm{C}$ required to prepare VN by the traditional CRN method, this study permitted a lower temperature and a shorter time by as much as several hundred degrees centigrade and several hours, respectively. The traditional raw materials were a mixture of $\mathrm{V}_{2} \mathrm{O}_{5}$ and $\mathrm{C}$, while a precursor with $\mathrm{V}$-coated $\mathrm{C}$ structure was applied in our research, a fact we consider an essential difference. Hence, we had to investigate the precursor. To understand the phase compositions of the precursor, XRD analysis was conducted. The result shown in Figure 6 revealed that the precursor consists of $\left(\mathrm{NH}_{4}\right)_{2} \mathrm{~V}_{6} \mathrm{O}_{16} \cdot 1.5 \mathrm{H}_{2} \mathrm{O}$ with a small amount of $\mathrm{NH}_{4} \mathrm{Al}\left(\mathrm{SO}_{4}\right)_{2} \cdot 12 \mathrm{H}_{2} \mathrm{O}$. No peaks can be indexed to $\mathrm{C}$, due to the amorphous state of carbon black. 


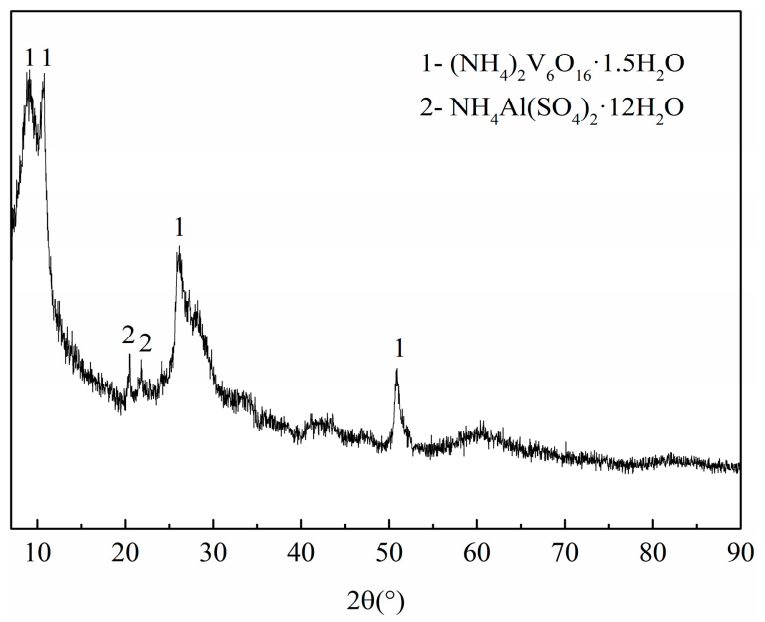

Figure 6. The XRD pattern of the precursor.

To have a visualized comprehension of the distribution of $\left(\mathrm{NH}_{4}\right)_{2} \mathrm{~V}_{6} \mathrm{O}_{16} \cdot 1.5 \mathrm{H}_{2} \mathrm{O}$ and carbon black in the precursor, SEM-EDS analysis was conducted and the results are presented in Figure 7. As shown in Figure 7a, there was $C$ in the center and $V$ was plentiful around $C$ in a single particle, which indicated that the carbon black was surrounded by vanadium during the process of vanadium precipitation. Figure $7 \mathrm{~b}$ is a partially enlarged view of the edge of the particle shown in Figure 7a. It can be clearly seen that $\mathrm{V}$ is located at the edge of the particle, with $\mathrm{C}$ being in the interior. There were many vanadium-coated carbon structures (V-coated C structures), as shown in the red circles in Figure 7c.
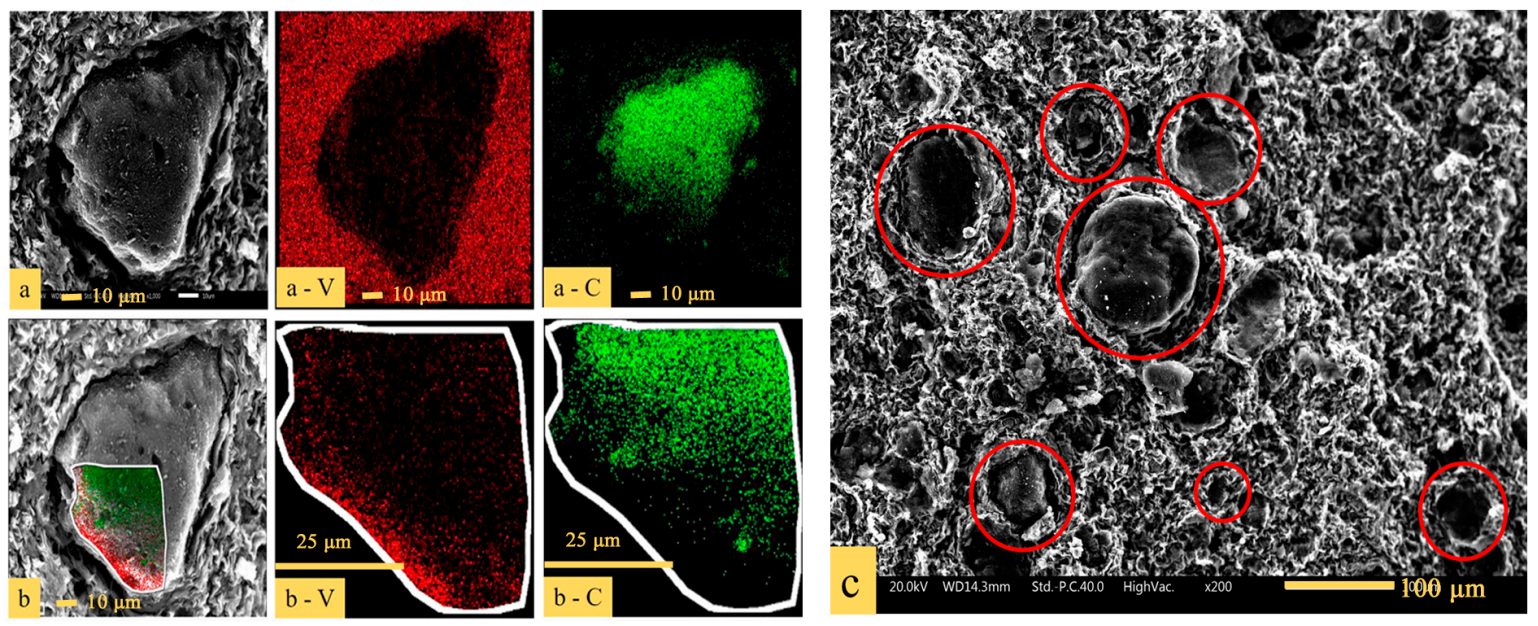

Figure 7. SEM (scanning electron microscope) images with EDS (energy-dispersive X-ray spectroscope) element mapping of: (a) The precursor; (b) the partial enlarged view of the edge of the particle; (c) SEM image of the overall distribution of the precursor.

The formation process of the V-coated C structure is schematically illustrated in Figure 8, where the black parts and orange parts represent carbon black and APV, respectively. Due to the presence of the dispered carbon black, the nuclei of the vanadium precipitates in the slurry grow on the surface of carbon black, which served as the heterogeneous nucleation site, instead of forming discrete precipitates. As the precipitation proceeded, APV particles grew gradually and coated carbon black completely, the typical coated structure formed with the core and the coating layer was carbon black and APV, respectively; the uncoated carbon black located around APV. The overall distribution of the precursor was the $\mathrm{V}$-coated $\mathrm{C}$ structure which was surrounded by the uncoated carbon black. 


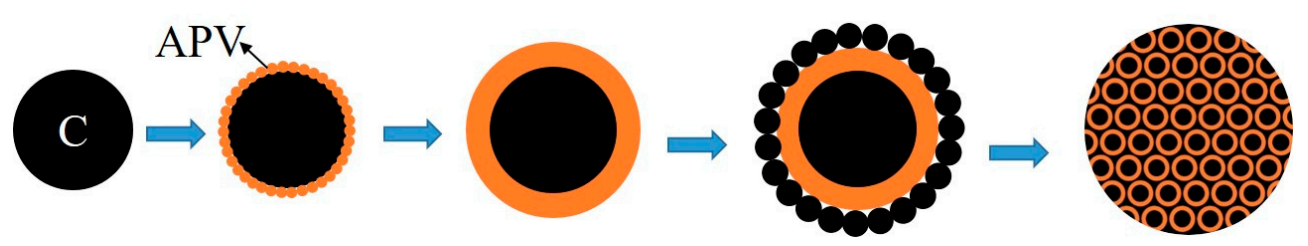

Figure 8. Formation process sketch of the precursor. (APV: Ammonium polyvanadate.)

The V-coated C structure evidently promoted the reaction between vanadium oxide and carbon black due to the following reasons. First, on the internal interphase of the V-coated C structure, $\mathrm{CO}$ produced by direct reduction of vanadium oxides by carbon black could not escape due to the coated structure; hence, it continued to react with vanadium oxide by indirect reduction. Subsequently, $\mathrm{CO}_{2}$ produced by indirect reduction will react with carbon black to produce $\mathrm{CO}$ at high temperature. That is to say, inside the vanadium oxides, the direct reduction and indirect reduction occur simultaneously at the internal interphase. Secondly, outside the vanadium oxides, the uncoated $\mathrm{C}$ reacted with vanadium oxides simultaneously on the external interphase. Lastly, the V-coated $\mathrm{C}$ structure increased the contact area between carbon black and vanadium oxides remarkably and provided a more homogeneous chemical composition than traditional mechanical blending. APV decomposed into $\mathrm{V}_{2} \mathrm{O}_{5}$ and $\mathrm{V}_{2} \mathrm{O}_{5}$ was reduced and nitrided gradually during the synthesis of VN. The coating structure always existed with the coating layer changing from APV to lower-valent vanadium oxides, vanadium carbide and vanadium nitride, until the precursor converted into VN completely. Hence, the V-coated C structure obtained by adding carbon black to the stripping solution before the precipitation of vanadium significantly reduced the reaction temperature and shortened the reaction time.

\subsection{Phase Evolution of Preparing VN from the Precursor}

The progress of the phase formation during the preparation of $\mathrm{VN}$ was monitored by interrupting the reaction intermittently at different temperatures and then the samples were analyzed by XRD analysis. Figure 9 shows the XRD patterns of the precursor and products at different temperatures.

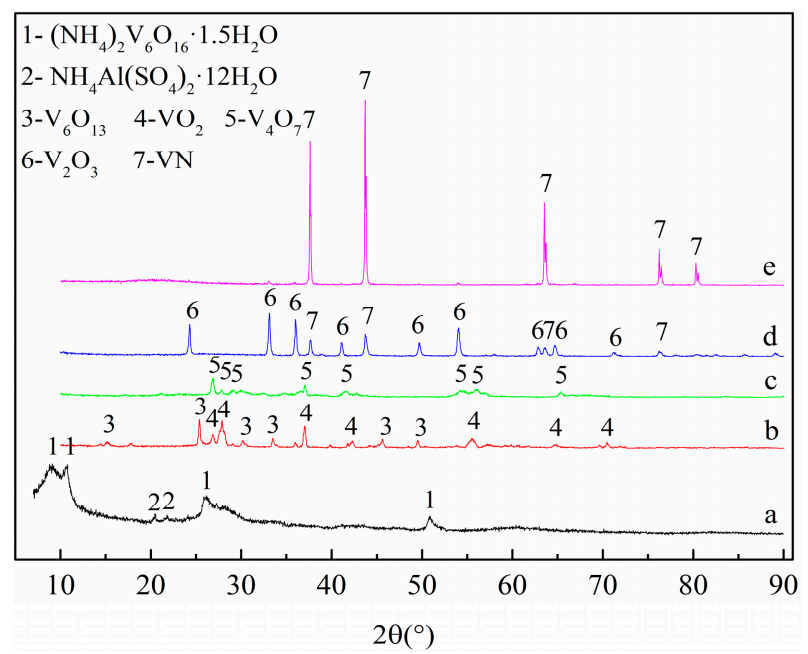

Figure 9. $\mathrm{XRD}$ patterns of the precursor and products at different temperatures with a $\mathrm{C} / \mathrm{V}_{2} \mathrm{O}_{5}$ mass ratio of 0.30: (a) The precursor; (b) $550{ }^{\circ} \mathrm{C}$; (c) $650{ }^{\circ} \mathrm{C}$; (d) $950{ }^{\circ} \mathrm{C}$; (e) $1150{ }^{\circ} \mathrm{C}$.

The precursor was composed of $\left(\mathrm{NH}_{4}\right)_{2} \mathrm{~V}_{6} \mathrm{O}_{16} \cdot 1.5 \mathrm{H}_{2} \mathrm{O}$ and a small amount of $\mathrm{NH}_{4} \mathrm{Al}\left(\mathrm{SO}_{4}\right)_{2} \cdot 12 \mathrm{H}_{2} \mathrm{O}$ as shown in curve (a). The diffraction peaks were identified as $\mathrm{V}_{6} \mathrm{O}_{13}$ and $\mathrm{VO}_{2}$ [32-35] in curve (b), attributed to the decomposition of $\left(\mathrm{NH}_{4}\right)_{2} \mathrm{~V}_{6} \mathrm{O}_{16} \cdot 1.5 \mathrm{H}_{2} \mathrm{O}$ into $\mathrm{V}_{2} \mathrm{O}_{5}$ and $\mathrm{NH}_{3}$; then, the $\mathrm{V}_{2} \mathrm{O}_{5}$ 
was initially reduced to $\mathrm{V}_{6} \mathrm{O}_{13}$ and $\mathrm{VO}_{2}$ by $\mathrm{NH}_{3}$ under $550{ }^{\circ} \mathrm{C}$. As shown in curve (c), all peaks corresponded to $\mathrm{V}_{4} \mathrm{O}_{7}$, which indicated that the further reduction of $\mathrm{V}_{6} \mathrm{O}_{13}$ and $\mathrm{VO}_{2}$ to $\mathrm{V}_{4} \mathrm{O}_{7}$ may be by the progressive reduction of $\mathrm{V}_{6} \mathrm{O}_{13}$ to $\mathrm{VO}_{2}$ and $\mathrm{VO}_{2}$ to $\mathrm{V}_{4} \mathrm{O}_{7}$ below $650^{\circ} \mathrm{C}$. The appearance of $\mathrm{V}_{2} \mathrm{O}_{3}$ and $\mathrm{VN}$ in curve (d) illustrates that $\mathrm{V}_{4} \mathrm{O}_{7}$ was reduced to $\mathrm{V}_{2} \mathrm{O}_{3}$ continuously and the VN phase was formed from $\mathrm{V}_{2} \mathrm{O}_{3}$ below $950{ }^{\circ} \mathrm{C}$. There was only a single phase of $\mathrm{VN}$ at $1150{ }^{\circ} \mathrm{C}$. Based on the above recorded phase changes, the possible mechanism of preparing $\mathrm{VN}$ could be formulated as follows:

$$
\begin{gathered}
\left(\mathrm{NH}_{4}\right)_{2} \mathrm{~V}_{6} \mathrm{O}_{16} \cdot 1.5 \mathrm{H}_{2} \mathrm{O}=3 \mathrm{~V}_{2} \mathrm{O}_{5}+2 \mathrm{NH}_{3} \uparrow+2.5 \mathrm{H}_{2} \mathrm{O} \\
3 \mathrm{~V}_{2} \mathrm{O}_{5}+2 \mathrm{NH}_{3}=\mathrm{V}_{6} \mathrm{O}_{13}+\mathrm{N}_{2} \uparrow+2 \mathrm{H}_{2} \mathrm{O}+\mathrm{H}_{2} \uparrow \\
3 \mathrm{~V}_{2} \mathrm{O}_{5}+2 \mathrm{NH}_{3}=6 \mathrm{VO}_{2}+\mathrm{N}_{2} \uparrow+3 \mathrm{H}_{2} \mathrm{O} \\
2 \mathrm{~V}_{6} \mathrm{O}_{13}+5 \mathrm{C}=3 \mathrm{~V}_{4} \mathrm{O}_{7}+5 \mathrm{CO} \uparrow \\
\mathrm{V}_{6} \mathrm{O}_{13}+\mathrm{C}=6 \mathrm{VO}_{2}+\mathrm{CO} \uparrow \\
4 \mathrm{VO}_{2}+\mathrm{C}=\mathrm{V}_{4} \mathrm{O}_{7}+\mathrm{CO} \uparrow \\
\mathrm{V}_{4} \mathrm{O}_{7}+\mathrm{C}=2 \mathrm{~V}_{2} \mathrm{O}_{3}+\mathrm{CO} \uparrow \\
2 \mathrm{~V}_{2} \mathrm{O}_{3}+2 \mathrm{~N}_{2}=4 \mathrm{VN}+3 \mathrm{O}_{2} \uparrow, \Delta G^{\theta}=1371222-82.73 T, \mathrm{~J} \cdot \mathrm{mol}^{-1} \\
\mathrm{~V}_{2} \mathrm{O}_{3}+5 \mathrm{C}=2 \mathrm{VC}+3 \mathrm{CO} \uparrow, \Delta G^{\theta}=535438.31-490.18 T, \mathrm{~J} \cdot \mathrm{mol}^{-1} \\
2 \mathrm{VC}+\mathrm{N}_{2}=2 \mathrm{VN}+2 \mathrm{C}, \Delta G^{\theta}=-185495.60+147.56 T, \mathrm{~J} \cdot \mathrm{mol}^{-1}
\end{gathered}
$$

According to the standard Gibbs free energy changes $\left(\Delta G^{\theta}(T)\right)$ of Reactions (8)-(10), calculated by the "Reaction" module of Factsage 7.1 software (Factsage 7.1, Thermfact/CRCT, Montreal, QC, Canada; GTT-Technologies, Aachen, Germany), the VN phase can be formed at $16,575{ }^{\circ} \mathrm{C}$ via $\mathrm{V}_{2} \mathrm{O}_{3}$ reacting directly with nitrogen under standard state conditions, while the VC phase can be formed at a lower temperature of about $1092{ }^{\circ} \mathrm{C}$. The transformation of $\mathrm{VC}$ to $\mathrm{VN}$ was spontaneous below $1257^{\circ} \mathrm{C}$. This means that intermediate formation of VC can occur and subsequently convert to $\mathrm{VN}$ when the temperature varies between $1092{ }^{\circ} \mathrm{C}$ and $1257^{\circ} \mathrm{C}$ under standard state conditions and in an extended range of temperatures in flowing nitrogen atmosphere, indicating that $1150{ }^{\circ} \mathrm{C}$ satisfies the thermodynamic conditions. Therefore, the phase evolution of $\left(\mathrm{NH}_{4}\right)_{2} \mathrm{~V}_{6} \mathrm{O}_{16} \cdot 1.5 \mathrm{H}_{2} \mathrm{O}$ to $\mathrm{VN}$ took place in the following sequential order:

$$
\left(\mathrm{NH}_{4}\right)_{2} \mathrm{~V}_{6} \mathrm{O}_{16} \cdot 1.5 \mathrm{H}_{2} \mathrm{O} \rightarrow \mathrm{V}_{2} \mathrm{O}_{5} \rightarrow \mathrm{V}_{6} \mathrm{O}_{13} \rightarrow \mathrm{VO}_{2} \rightarrow \mathrm{V}_{4} \mathrm{O}_{7} \rightarrow \mathrm{V}_{2} \mathrm{O}_{3} \rightarrow \mathrm{VC} \rightarrow \mathrm{VN}
$$

It is worth noting that after being heated at $550{ }^{\circ} \mathrm{C}$ for $20 \mathrm{~min}$, the precursor converted completely to low-valent vanadium oxides $\mathrm{V}_{6} \mathrm{O}_{13}$ and $\mathrm{VO}_{2}$ without the appearance of residual unreacted $\mathrm{V}_{2} \mathrm{O}_{5}$, which has a low melting point $\left(670{ }^{\circ} \mathrm{C}\right)$ and high saturation vapor pressure. $\mathrm{V}_{6} \mathrm{O}_{13}$ can decompose to $\mathrm{VO}_{2}$ at $700{ }^{\circ} \mathrm{C}$, and $\mathrm{VO}_{2}$ has a high melting point of $1542{ }^{\circ} \mathrm{C}$ [36]. Thus, the pre-reduction at $650{ }^{\circ} \mathrm{C}$ for $2.5 \mathrm{~h}$ can be eliminated in this process.

TG experiments were carried out under $\mathrm{N}_{2}$ atmosphere to reflect the physical and chemical phenomena in the preparation process of VN. TG and DTG (differential thermogravimetric) curves of the precursor are shown in Figure 10. There were four major weight losses indicated by four DTG peaks in the DTG curve. The first major weight loss between room temperature and $136{ }^{\circ} \mathrm{C}$ was attributed to the evaporation of physically absorbed and crystalline water. The second major weight loss from $380^{\circ} \mathrm{C}$ to $447^{\circ} \mathrm{C}$ was due to the decomposition of $\mathrm{APV}$ and the initial reduction of $\mathrm{V}_{2} \mathrm{O}_{5}$ to $\mathrm{V}_{6} \mathrm{O}_{13}$ and $\mathrm{VO}_{2}$, which corresponded to the Reactions (1)-(3). The third weight loss corresponded to the further reduction of $\mathrm{V}_{6} \mathrm{O}_{13}$ and $\mathrm{VO}_{2}$ to $\mathrm{V}_{4} \mathrm{O}_{7}$ according to Reactions (4)-(6). In this stage, the absolute value of weight loss rates first increased, then decreased and eventually increased again at the temperatures of $600{ }^{\circ} \mathrm{C}-653^{\circ} \mathrm{C}, 653{ }^{\circ} \mathrm{C}-660^{\circ} \mathrm{C}$ and $660^{\circ} \mathrm{C}-700{ }^{\circ} \mathrm{C}$, respectively. The absolute value of weight loss rate 
escalated with increasing temperature because the reduction reaction was endothermic and increasing the temperature promoted the reduction. The absolute value of weight loss rate decreased as the reaction progressed. The increase of the weight loss rate was due to the decomposition of $\mathrm{V}_{6} \mathrm{O}_{13}$ to $\mathrm{VO}_{2}$; the maximum, absolute value of the weight loss rate at $700{ }^{\circ} \mathrm{C}$ corresponded to the decomposition temperature of $\mathrm{V}_{6} \mathrm{O}_{13}$. The last weight loss was assigned to the phase transformation from $\mathrm{V}_{4} \mathrm{O}_{7}$ to $\mathrm{V}_{2} \mathrm{O}_{3}$ and $\mathrm{V}_{2} \mathrm{O}_{3}$ to the desired phase $\mathrm{VN}$, which corresponded to Reactions (7), (9) and (10).

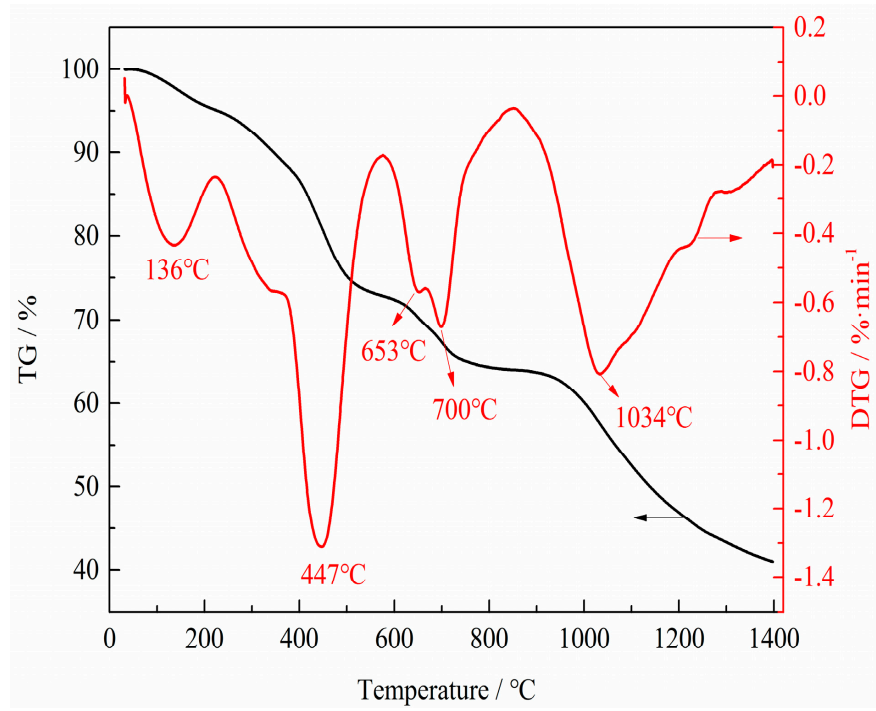

Figure 10. TG (thermogravimetric) and DTG (differential thermogravimetric) curves of the precursor from $30{ }^{\circ} \mathrm{C}$ to $1400{ }^{\circ} \mathrm{C}$ with a linear heating rate of $10^{\circ} \mathrm{C} \cdot \mathrm{min}^{-1}$ and $\mathrm{N}_{2}$ flow rate of $50 \mathrm{~mL} \cdot \mathrm{min}^{-1}$.

\section{Conclusions}

A novel synthesis method of a $\left(\mathrm{NH}_{4}\right)_{2} \mathrm{~V}_{6} \mathrm{O}_{16} \cdot 1.5 \mathrm{H}_{2} \mathrm{O}$ precursor to prepare $\mathrm{VN}$ was proposed, characterized by adding carbon black to the stripping solution during the vanadium recovery from black shale. VN with an $\mathrm{N}$ content of $16.38 \%$ was successfully prepared by thermal processing of the precursor at $1150{ }^{\circ} \mathrm{C}$ for $1 \mathrm{~h}$ with a $\mathrm{C} / \mathrm{V}_{2} \mathrm{O}_{5}$ mass ratio of 0.30 and a $\mathrm{N}_{2}$ flow rate of $300 \mathrm{~mL} \cdot \mathrm{min}^{-1}$. Low synthesis temperature and short period for the preparation of $\mathrm{VN}$ was due to the $\mathrm{V}$-coated $C$ structure of the precursor, which enlarged the contact area between reactants significantly and provided a more homogeneous chemical composition. In addition, the simultaneous direct reduction and indirect reduction at the interphase caused by the coating structure evidently accelerated the reaction. XRD patterns and thermodynamic analysis indicated that the phase evolution from the precursor to $\mathrm{VN}$ took place in the following order $\left(\mathrm{NH}_{4}\right)_{2} \mathrm{~V}_{6} \mathrm{O}_{16} \cdot 1.5 \mathrm{H}_{2} \mathrm{O} \rightarrow \mathrm{V}_{2} \mathrm{O}_{5} \rightarrow \mathrm{V}_{6} \mathrm{O}_{13} \rightarrow \mathrm{VO}_{2}$ $\rightarrow \mathrm{V}_{4} \mathrm{O}_{7} \rightarrow \mathrm{V}_{2} \mathrm{O}_{3} \rightarrow \mathrm{VC} \rightarrow \mathrm{VN}$. The precursor converted to $\mathrm{V}_{6} \mathrm{O}_{13}$ and $\mathrm{VO}_{2}$ completely after being calcined at $550{ }^{\circ} \mathrm{C}$, indicating that the pre-reduction of $\mathrm{V}_{2} \mathrm{O}_{5}$ in the traditional CRN method can be dispensed with. Therefore, this method is an effective, simple and low-cost route to prepare VN.

Acknowledgments: This research was funded by the National Natural Science Foundation of China (No. 51404174 and No. 51474162) and the Project in the National Science \& Technology Pillar Program of China (No. 2015BAB18B01).

Author Contributions: Jingli Han and Yimin Zhang conceived and designed the experiments; Jingli Han performed the experiments and analyzed the data; Yimin Zhang, Tao Liu and Jing Huang contributed reagents, materials and analysis tools; Nannan Xue and Pengcheng Hu provided valuable scientific advice for the study; Jingli Han wrote the paper.

Conflicts of Interest: The authors declare no conflict of interest. 


\section{References}

1. Huang, J.; Peng, H.; Xia, G. Microwave synthesis of vanadium nitride for industrial applications. Ironmak. Steelmak. 2009, 36, 110-114. [CrossRef]

2. Yu, S.; Li, W.; Ji, Z.; Fu, N.; Sui, Z. Effect of technical parameters on preparing for vanadium nitride. Adv. Mater. Res. 2010, 150-151, 480-483. [CrossRef]

3. Morel, A.; Piron, Y.B.; Porto, R.L.; Brousse, T.; Belanger, D. Suitable conditions for the use of vanadium nitride as an electrode for electrochemical capacitor. J. Electrochem. Soc. 2016, 163, A1077-A1082. [CrossRef]

4. Zhou, X.; Chen, H.; Shu, D.; He, C.; Nan, J. Study on the electrochemical behavior of vanadium nitride as a promising supercapacitor material. J. Phys. Chem. Solids 2009, 70, 495-500. [CrossRef]

5. Wu, M.; Guo, H.; Lin, Y.; Wu, K.; Ma, T.; Hagfeldt, A. Synthesis of highly effective vanadium nitride (VN) peas as a counter electrode catalyst in dye-sensitized solar cells. J. Phys. Chem. C 2014, 118, 12625-12631. [CrossRef]

6. Krawiec, P.; Cola, P.L.D.; Gläser, R.; Weitkamp, J.; Weidenthaler, C.; Kaskel, S. Oxide foams for the synthesis of high-surface-area vanadium nitride catalysts. Adv. Mater. 2006, 18, 506-508. [CrossRef]

7. Gajbhiye, N.S.; Ningthoujam, R.S. Low temperature synthesis, crystal structure and thermal stability studies of nanocrystalline VN particles. Mater. Res. Bull. 2006, 41, 1612-1621. [CrossRef]

8. Smolik, J.; Mazurkiewicz, A.; Słomka, Z.; Bujak, J.; Gołacka, J.K.; Garbacz, H.; Wieciński, P. Nanomultilayer coatings based on vanadium nitride. Solid State Phenom. 2015, 237, 15-20. [CrossRef]

9. Caicedo, J.C.; Zambrano, G.; Aperador, W.; Escobar-Alarcon, L.; Camps, E. Mechanical and electrochemical characterization of vanadium nitride (VN) thin films. Appl. Surf. Sci. 2011, 258, 312-320. [CrossRef]

10. Duan, X.; Srinivasakannan, C.; Zhang, H.; Zhang, Y. Process optimization of the preparation of vanadium nitride from vanadium pentoxide. Arab. J. Sci. Eng. 2015, 40, 2133-2139.

11. Tripathy, P.K.; Sehra, J.C.; Kulkarni, A.V. On the carbonitrothermic reduction of vanadium pentoxide. J. Mater. Chem. 2001, 11, 691-695. [CrossRef]

12. Pan, H.; Zhang, Z.; Peng, J.; Zhang, L.; Li, W. Densification of vanadium nitride by microwave-assisted carbothermal nitridation. Adv. Mater. Res. 2011, 201-203, 1787-1792. [CrossRef]

13. Chen, Z.; Xue, Z.; Wang, W.; Yu, Y.; Liu, Q.; Li, P. One-step method of carbon thermal reduction and nitride to produce vanadium nitrogen alloy. Adv. Mater. Res. 2012, 476-478, 194-198. [CrossRef]

14. Cai, P.; Yang, Z.; Wang, C.; Xia, P.; Qian, Y. Synthesis of nanocrystalline VN via thermal liquid-solid reaction. Mater. Lett. 2006, 60, 410-413. [CrossRef]

15. Yeh, C.L.; Chen, Y.D. Combustion synthesis of vanadium carbonitride from V-C powder compacts under nitrogen pressure. Ceram. Int. 2007, 33, 365-371. [CrossRef]

16. Cheng, F.; He, C.; Shu, D.; Chen, H.; Zhang, J.; Tang, S.; Finlow, D.E. Preparation of nanocrystalline VN by the melamine reduction of $\mathrm{V}_{2} \mathrm{O}_{5}$ xerogel and its supercapacitive behavior. Mater. Chem. Phys. 2011, 131, 268-273. [CrossRef]

17. Azargohar, R.; Dalai, A.K. Production of activated carbon from luscar char: Experimental and modeling studies. Microporous Mesoporous Mater. 2005, 85, 219-225. [CrossRef]

18. Zhang, B.; Li, Z. Synthesis of vanadium carbide by mechanical alloying. J. Alloys Compd. 2005, 392, $183-186$. [CrossRef]

19. Yao, W.; Makowski, P.; Giordano, C.; Goettmann, F. Synthesis of early-transition-metal carbide and nitride nanoparticles through the urea route and their use as alkylation catalysts. Chem. Eur. J. 2009, 15, 11999-12004. [CrossRef] [PubMed]

20. Chen, L.; Gu, Y.; Shi, L.; Yang, Z.; Ma, J.; Qian, Y. A room-temperature synthesis of nanocrystalline vanadium nitride. J. Eur. Ceram. Soc. 2010, 30, 2099-2107. [CrossRef]

21. Zhao, Z.; Liu, Y.; Cao, H.; Ye, J.; Gao, S.; Tu, M. Synthesis of VN nanopowders by thermal nitridation of the precursor and their characterization. J. Alloys Compd. 2008, 464, 75-80. [CrossRef]

22. Liu, A.; Liu, Y.; Ma, S.; Qiu, Y.; Rong, P.; Ye, J. Synthesis of $(\mathrm{Cr}, \mathrm{V})_{2}(\mathrm{C}, \mathrm{N})$ solid solution powders by thermal processing precursors. Mater. Chem. Phys. 2017, 193, 196-202. [CrossRef]

23. Cai, Z.; Zhang, Y.; Liu, T.; Huang, J. Mechanisms of vanadium recovery from stone coal by novel $\mathrm{BaCO}_{3} / \mathrm{BaO}$ composite additive roasting and acid leaching technology. Minerals 2016, 6, 26. [CrossRef]

24. Zhang, X.; Yang, K.; Tian, X.; Qin, W. Vanadium leaching from carbonaceous shale using fluosilicic acid. Int. J. Miner. Process. 2011, 100, 184-187. [CrossRef] 
25. Zhang, Y.; Bao, S.; Liu, T.; Huang, J. The technology of extracting vanadium from stone coal in China: History, current status and future prospects. Hydrometallurgy 2011, 109, 116-124. [CrossRef]

26. Liu, Y.; Yang, C.; Li, P.; Li, S. A new process of extracting vanadium from stone coal. Int. J. Miner. Metall. Mater. 2010, 17, 381-388. [CrossRef]

27. Nguyen, T.; Lee, M. Solvent extraction of vanadium (V) from sulfate solutions using LIX 63 and PC 88A. J. Ind. Eng. Chem. 2015, 31, 118-123. [CrossRef]

28. Li, X.; Wei, C.; Deng, Z.; Li, M.; Li, C.; Fan, G. Selective solvent extraction of vanadium over iron from a stone coal/black shale acid leach solution by D2EHPA/TBP. Hydrometallurgy 2011, 105, 359-363. [CrossRef]

29. Li, X.; Wei, C.; Deng, Z.; Li, C.; Fan, G.; Li, M.; Huang, H. Recovery of vanadium from $\mathrm{H}_{2} \mathrm{SO}_{4}-\mathrm{HF}$ acidic leaching solution of black shale by solvent extraction and precipitation. Metals 2016, 6, 63. [CrossRef]

30. Gu, H.M.; Shih, W.Y.; Shih, W.H. Single-calcination synthesis of pyrochlore-free $0.9 \mathrm{~Pb}\left(\mathrm{Mg}_{1 / 3} \mathrm{Nb}_{2 / 3}\right) \mathrm{O}_{3}-0.1 \mathrm{PbTiO}_{3}$ and $\mathrm{Pb}\left(\mathrm{Mg}_{1 / 3} \mathrm{Nb}_{2 / 3}\right) \mathrm{O}_{3}$ Ceramics Using a Coating Method. J. Am. Ceram. Soc. 2003, 86, 217-221. [CrossRef]

31. Ivashchenko, V.I.; Turhci, P.E.A. Phonon softening and the phase transition in VN. Phys. Rev. B 2008, 78, 224113. [CrossRef]

32. Vernardou, D.; Apostolopoulou, M.; Louloudakis, D.; Spanakis, E.; Katsarakis, N.; Koudoumas, E.; McGrath, J.; Pemble, M.E. Electrochemical properties of opal- $\mathrm{V}_{6} \mathrm{O}_{13}$ composites. J. Alloys Compd. 2014, 586, 621-626. [CrossRef]

33. Vernardou, D.; Pemble, M.E.; Sheel, D.W. In-situ FTIR studies of the growth of vanadium dioxide coatings on glass by atmospheric pressure chemical vapour deposition for $\mathrm{VCl}_{4}$ and $\mathrm{H}_{2} \mathrm{O}$ system. Thin Solid Films 2007, 515, 8768-8770. [CrossRef]

34. Vernardou, D.; Louloudakis, D.; Spanakis, E.; Katsarakis, N.; Koudoumas, E. Functional properties of APCVD VO 2 layers. Int. J. Thin Films Sci. Technol. 2015, 4, 187-191.

35. Vernardou, D.; Bei, A.; Louloudakis, D.; Katsarakis, N.; Koudoumas, E. Oxygen source-oriented control of atmospheric pressure chemical vapor deposition of $\mathrm{VO}_{2}$ for capacitive applications. J. Electrochem. Sci. Eng. 2016, 6, 165-173.

36. Bennett, L.H.; Massalski, T.B.; Giessen, B.C. Alloy Phase Diagrams. Mater. Res. Soc. Symp. Proc. 1983, 19.

(C) 2017 by the authors. Licensee MDPI, Basel, Switzerland. This article is an open access article distributed under the terms and conditions of the Creative Commons Attribution (CC BY) license (http:/ / creativecommons.org/licenses/by/4.0/). 